\title{
Erken çocukluk gelişimine dair Türkiye bulgularına bakış ${ }^{*}$
}

\author{
Early child development: Research from Turkey
}

\author{
Makale Geçmişi \\ Geliş : :01 Şubat 2018 \\ Düzeltme : 08 Şubat 2018 \\ Kabul : 09 Şubat 2018 \\ Makale Türü \\ Derleme Makale
}

\section{Article History}

Received : 01 February 2018

Revised : 08 February 2018

Accepted : 09 February 2018

Article Type

Review Article

\author{
Bilge Selçuk ${ }^{1}, H$. Melis Yavuz ${ }^{2}$
}

Öz: Erken çocukluk, beynin gelişiminin en yoğun olduğu, bilişsel ve sosyal becerilerin temellerinin atıldığı bir dönemdir. $\mathrm{Bu}$ makalede, erken çocukluk döneminde ortaya çıkan becerilerin bağlantılarını ve gelişimlerinde rolü olan unsurları farklı örneklemlerde (tipik ve atipik gelişim gösteren çocuklar, tipik ve atipik gelişimsel bağlamlarda yetişenler) incelediğimiz araştırmalarımızı özetliyor, sonuçlarını diğer literatür bulgularıyla birlikte değerlendiriyoruz. Bulgular iki becerinin, alıcı dil ve yönetici işlev becerilerinin çocuğun psikolojik esenliği ve optimal gelişimi için kritik olduğunu ortaya koyuyor. Bu becerilerin gelişimine hangi unsurların nasıl etki ettiğini gösteren araştırma sonuçlarımızı derliyor, uygulamaya dair önermelerini tartışıyoruz.

Anahtar Kelimeler: Erken çocukluk, gelişim, yönetici işlev, dil becerisi, alıcı dil, çevre, psikoloji

Abstract: Early childhood is a period during which brain development is at its highest and the social and cognitive skills start to develop. In this paper, we summarized our studies in which we investigate the skills that emerge in early childhood years, and the factors associated with the development of these skills in different populations (typically developing children and children with atypical development, typical and atypical rearing contexts). We examine our results in light of the findings of the previous literature. The results of our studies suggest that two skills, namely receptive language and executive function are critical for psychological well-being and optimal development. In this review we compile our findings about the factors influencing the development of these skills, the mechanisms of this influence. We also discuss the applied implications of our findings.

Keywords: Early childhood, development, executive function, language, receptive language, environment, psychology

\footnotetext{
* 5.Uluslararası Okul Öncesi Eğitim Kongresinde “çăgrılı konuşma” olarak sunulmuştur.

${ }^{1}$ Koç Üniversitesi, İnsani Bilimler ve Edebiyat Fakültesi, Psikoloji Bölümü, bselcuk@ku.edu.tr

${ }^{2}$ MEF Üniversitesi, İktisadi, İdari ve Sosyal Bilimler Fakültesi, Psikoloji Bölümü, murenm@mef.edu.tr
} 


\section{SUMMARY}

\section{Introduction}

About $90 \%$ of physical development in the human brain is completed before the age of five (Huttenlocher, 1994). This indicates that early childhood is a critical period for the development of important social, cognitive, and linguistic skills. It also implies that early childhood might be a critical period to intervene in certain skills to improve concurrent and future outcomes. Describing the associations between variables and understanding which variables are associated with which developmental outcomes are important. However, the main aim of developmental science is to uncover the mechanisms of development in order to predict, control, and change outcomes when necessary. With this aim, at the Koç University Child and Family Studies Laboratory we conduct studies to reveal mechanisms for certain developmental outcomes in the early childhood years. We investigate these developmental mechanisms in: typically developing children; atypical populations including children with autism (e.g., Yavuz, Selçuk, \& Korkmaz, 2017a); children with developmental disabilities (Yağmurlu \& Yavuz, 2015); children with hearing impairments (e.g., Alaylı \& Yağmurlu, 2015); children raised in institutions (e.g., Selçuk, Yavuz, Harma, Etel, \& Ruffman, 2017); and children in immigration contexts (e.g., Yağmurlu \& Sanson, 2009). In our studies we do not only rely on parent reports but also use structured and semi-structured observational methods, individual assessments, and interviews. Whenever possible, we use multiple informants (e.g., mothers, fathers, teachers; e.g., Yağmurlu, 2015). This allows us to extensively investigate the similarities and differences of developmental mechanisms in typical and atypical groups. Our studies revealed two skills in early childhood years as being critical for concurrent and longitudinal social, socio-cognitive, and behavioral outcomes: namely language and executive function skills. In this review paper, we summarize the research that we have conducted with Turkish children in early childhood years, focusing on the developmental precursors of language and executive function, and the outcomes related to these two skills.

\section{Language and development in early childhood}

Various studies have investigated the association of linguistic skills with social competence and sociocognitive capacities of children within atypical developmental groups. In one such study, Etel and Yağmurlu (2015) found that receptive language was positively related to the social competence of preschoolers (3-5-year-olds; $N=107)$ residing in institutions, controlling for theory of mind (ToM) understanding, and executive function (EF). Moreover, receptive language was directly and positively related to $\mathrm{EF}$ and indirectly related to ToM via $\mathrm{EF}$, showing both the direct and indirect role of receptive language on socio-cognitive outcomes. In another study, Yavuz et al. (2017) found that among verbal and non-verbal communication skills, and cognitive representation skills (understanding mental and internal states), only the non-verbal communication skills were positively and significantly related to 
the social competence of children with autism spectrum disorder $\left(\mathrm{M}_{\text {age }}=8.5\right.$ years; $\left.N=45\right)$. With hearing-impaired children (3-13-year-olds, $N=70$ ), the results showed that children with better receptive language had better ToM understanding, EF, and lower aggression (Alaylı \& Yağmurlu, 2015). In sum, these studies on atypical populations showed that language is an important predictor for social and socio-cognitive development.

Since language is an important predictor of developmental outcomes, it is important to investigate the predictors of linguistic skills in early childhood years. In one study, Ekerim and Selçuk (2017) longitudinally examined different aspects of maternal-sensitive parenting (warmth and inductive reasoning) and child $\mathrm{EF}$ as predictors of preschoolers' $\left(\mathrm{M}_{\mathrm{age}}=4.5\right.$ years, $\left.N=239\right)$ vocabulary knowledge. Their results revealed that earlier maternal inductive reasoning (but not warmth) and child EF contributed to higher child vocabulary knowledge one year later (at T2). The results also showed family socio-economic status was directly and indirectly (via increasing maternal inductive reasoning and child EF) related to higher vocabulary knowledge at T2. Similarly, in another study Baydar et al. (2014) found that the receptive language of 3-year-old children in a nationally representative sample $(N=1017)$ was related to language stimulation and learning materials at home. Both of these results showed the importance of the rearing environment on linguistic development.

\section{Executive function and development in early childhood}

Executive function is another skill that develops in early childhood years and is related to various developmental outcomes (e.g., aggression). In general, the studies that we have conducted with Turkish children showed that children with better EF displayed lower aggression (Korucu, Selçuk, \& Harma, 2017) and better social relations (e.g., Korucu et al., 2017; Orta et al., 2013). Our studies also revealed that parenting has an important impact on the development of EF. Gündüz, Yağmurlu, and Harma (2015) showed that high maternal depression was related to lower responsiveness and higher power assertion in mothers, which are in turn related to lower EF in preschool children (3-6-year-olds; $N=217)$. In the same study, lower EF was also found to be related to lower social competence in preschoolers. Another study with preschool children (3-5-year-olds; $N=118)$ found that higher responsive parenting was related to better EF, and better EF was related to lower externalizing behaviors and higher social competence (Orta ve ark., 2013). With institutionalized preschool aged children, Selçuk et al. (2017) showed that early EF was positively related to social competence one year later. Therefore, these studies showed that parenting is also an important predictor of EF, which is related to various child developmental outcomes.

\section{Conclusion}

In general, our studies suggest that language and EF are the two most important skills that develop in early childhood years and that influence various developmental outcomes. These results have important implications for intervention studies and for educators, providing information about possible factors that 
might aid the development of these skills, and about the developmental outcomes that might be ameliorated with early intervention in these skills. 


\section{GíRIȘ}

Erken çocukluk, biliş, dil ve sosyal alanlardaki becerilerin gelişimi için çok önemli bir dönemdir. Beyin görüntüleme yöntemine dayanan gelişim psikolojisi ve nöropsikoloji araştırmaları beynin fiziksel gelişiminin yaklaşık \%90'ının 5 yaşından önce tamamlandığını gösterir (Huttenlocher, 1994). Beyin gelişimi erken çocukluk döneminden sonra da elbette devam eder, ancak en önemli gelişim bu dönemde olur ve belli bazı kritik becerilerin temelleri okul öncesi dönemde atılır. Bu sebeple, bu derleme makalesinde, Türkiye’den farklı örneklem grupları ile yaptığımız araştırmaların erken çocukluktaki gelişim üzerine verdiği bilgileri özetleyerek sunmak istedik.

Çocuk gelişimi literatürüne baktığımızda, en fazla incelenen unsurların çocuğun ev ortamı ve maruz kaldığı anne-babalık davranışları olduğunu görürüz. Olumlu bir ev ortamında büyüyen, duyarlı ve şefkatli anneler tarafından yetiştirilen çocukların anneleri ile güvenli bağlanma ilişkisi kurdukları ve bu güvenli bağlanmanın çocuğun gelişimine pozitif etki yaptığı pek çok araştırma tarafından ortaya konmuştur (bkz., Brumariu ve Kerns, 2011; Cassidy, 2008; DeKlyen ve Greenberg, 2008). Anne-çocuk arasındaki bu güvenli bağlanma ilişkisi, çocuğun mizaç özelliklerinden (örneğin ürkeklik) bağımsız olarak annenin duyarlı davranışlarına bağlıdır (Kochanska, 1998). Yani, güvenli bağlanmanın en önemli yordayıcısı duyarlı ebeveynliktir. Anne şefkatinin önemine dair bulgular, hayvan araştırmaları ile de desteklenir. Siçan, şempanze, maymun gibi memeli hayvanlar ile ve balık gibi memeli olmayan hayvanlar ile yapılan çalışmalar da anneleri tarafından sıcaklık gören yavruların psikolojik ve fiziksel olarak daha sağlıklı olduklarını, daha olumlu ve uyumlu sosyal davranışlar gösterdiklerini ortaya koymuştur (örn., Caldji ve ark., 1998; Mathuru ve ark., 2012). Öte yandan, tüm fiziksel ihtiyaçları karşılanmasına rağmen anne şefkati görmeyen memeli bebeklerin gelişimlerinin geriden geldiği, fiziksel ve ruhsal sağlıklarının belirgin şekilde bozulduğu, kendi gruplarındaki diğer hayvanlar ile iyi sosyal ilişkiler kuramadıkları, yaşam sürelerinin daha kısa olduğu bulunmuştur (örm., Harlow ve Harlow, 1962). Erken doğum, prematüre doğum gibi durumlarda da anne ile fiziksel temas bebeğin sağlığını iyileştirici etkiye sahiptir (Charpak, Ruiz-Pelaez, Figueroa de Calume ve Charpak, 2001; Morris, 2007). Özetle, anne davranışlarının ve anneçocuk arasındaki güvenli bağlanma ilişkisinin çocuğa yaptığı kritik pozitif etki hem insan hem hayvan araştırmaları tarafindan defaten gösterilmiştir.

Fakat belirtmek gerekir ki, anne-çocuk ilişkisinin çocuktaki gelişimsel çıktılar ile bağlantısını ortaya koyan bu önemli bulgular betimleyici olmaktan öteye gitmez. Oysa bir bilim olarak psikolojinin amacı sadece betimlemek değil, bu bağlantıların mekanizmalarını ortaya çıkarmak, 
bir başka deyişle, bu bağlantıların neden ve nasıl olduğunu açıklamak ve bu sayede gerektiğinde gelişimsel çıktıları kontrol edebilmek ve değiştirebilmektir. Dolayısıyla sormamız gereken önemli sorulardan biri, bu bilinen bağlantıların oluşmasını sağlayan etki mekanizmalarının neler olduğudur. Başka bir deyişle, sadece korelasyonel/bağlantısal ilişkilerden söz etmek yerine etki mekanizmalarını ortaya çıkartmak, hangi gelişimsel dönemdeki ne tür deneyimlerin hangi becerileri ne şekilde etki ettiğini ortaya koymak gelişim biliminin esas hedeflerinden olmalidir.

Koç Üniversitesi Çocuk ve Aile Çalışmaları Laboratuvarı'nda yaptığımız araştırmalarda bu hedefin önemini akılda tutarak, çocukların sosyal, dil ve bilişsel gelişimini değerlendiriyor, bu alanlardaki becerilere etki eden belli başlı aile ortamı ve ebeveynlik özelliklerini inceliyoruz. Sosyal gelişim alanında sosyal yetkinlik, olumlu sosyal davranış, duygusal yetkinlik (duygu tanıma becerisi, duygu düzenleme becerisi), dışa yönelim sorunları (saldırganlık, karşı gelme, şiddet) ve içe yönelim sorunlarına (anksiyete, depresyon) odaklanıyoruz. Dil becerisi kapsamında alıcı dil gelişimini, yani çocuğun kelime dağarcığını (bildiği kelime sayısını) ölçmeye önem veriyoruz. Bunun bir sebebi, alıcı dil becerisinin literatürde bilişsel ve sosyal gelişimin kuvvetli yordayıcılarından biri olarak belirmesidir (örn., Gertner, Rice ve Hadley, 1994; Hughes ve Ensor, 2008). Bilişsel gelişimi inceleyen araştırmalarımız ise zihin kuramı, yönetici işlev ve zaman zaman da sosyal bilgi işleme becerilerine odaklanmakta.

Aile özellikleri kapsamında, annelerin çocuk yetiştirme davranışlarını, yani duyarlılık, sıcaklık, açıklayıcı akıl yürütme gibi destekleyici davranışlarını ve güç gösterimi, katı disiplin gibi olumsuz kontrol davranışlarını inceliyoruz (örn., Ekerim ve Selçuk, 2017; Yavuz, Selçuk, Çorapçı ve Aksan, 2017b). Bunların yanı sıra, annelerin ebeveynlik değer, tutum, çocuğun doğası ve gelişimine dair düşünce gibi bilişlerini ve bu biliş ve davranışlara etki eden diğer ebeveyn özelliklerini (depresyon gibi psikiyatrik problemler, stres, esenlik vb.) de araştırıyoruz (Gülseven ve ark., 2017; Yavuz ve ark., 2017b; bkz., Yağmurlu ve Yavuz, 2012). Çocukların dil gelişimi ile ilişkili olarak annelerin eğitim düzeyi, kelime bilgileri, evdeki eğitici materyallerin varlığı da incelenen değişkenlerden. Ailenin sosyo-ekonomik düzeyi, hem ebeveynliğe ve aile ortamına hem de çocuğun gelişimine doğrudan ve dolaylı etkileri bakımından elbette tüm araştırmalarda ölçtüğümüz temel bir demografik değişken.

Aileler ve çocukların özellikleri ile ilgili tüm bu değişkenleri değerlendirirken sadece kişinin kendi bildirimine dayalı ölçeklerden, anketlerden yararlanmak yeterli değildir. Mümkün olan her durumda bireysel değerlendirme, gözlem, öğretmen ve akran bildirimine dayanan çoklu ölçüm yöntemlerinin kullanılması araştırmaları kuvvetlendirir. Biz de araştırmalarımızda buna 
dikkat ediyor, birebir yapılan uygulamaların standart olması için özellikle bilgisayarda verilen testlerden yararlanıyoruz. Yine mümkün olan durumlarda, çocuğun evinde veya laboratuvar ortamında yapılandırılmış veya yarı-yapılandırılmış yöntemler ile gözlemsel veri topluyoruz. Gözlem ile özellikle çocukların mizacı ve farklı özellikteki anne-çocuk etkileşimleri sırasında annelerin gösterdikleri ebeveynlik davranışlarını ölçüyoruz. Bu amaçla, anne ve/veya çocukları ev veya laboratuvar ortamında, farklı etkinlikler sırasında videoya kaydediyor, daha sonra bu kamera kayıtlarını kısa bölümlere ayırıp ölçülen mizaç özelliğinin veya ebeveynlik davranışının gerektirdiği davranışları çocuğun veya annenin gösterip göstermediğini ve göstereme derecelerini değerlendiriyoruz. Örneğin, bir araştırmada Laboratuvar ortamında Mizaç Ölcüm Bataryas1 (Laboratory Temperament Assessment Battery; Goldsmith ve Rothbart, 1996) içinden standardize edilmiş bir oyun (baloncuk patlatma oyunu-Bubbles episode) kullanarak okul öncesi dönemdeki çocukların coşkulu mizaç özeliklerini ölçtük. Laboratuvar ortamındaki bu ölçüm sırasında elde edilen video kayıtlarını 30'ar saniyelik parçalara bölüp, her bir bölümde gülme, kahkaha atma, olumlu sözcüklerin kullanımı, yüksek enerjili davranışlar gibi olumlu duygulanım ve coşkulanım gösteren davranışları çocuğun ne kadar yaptığını, yapma sıklığını ve derecesini kodladik (Yavuz ve ark., 2017b).

Annelerin çocuklarına yönelik davranışlarını ölçtüğümüz bir başka araştırmamızda (Yağmurlu, 2015), ev ortamında yarı-yapılandırılmış gözlemsel yöntemler ile annelerin çocuklarına gösterdikleri olumlu ve olumsuz ebeveynlik davranışlarını iki farklı durumda gözlemledik. Bu durumlardan ilkinde annelerden çocukları ile oyun oynamalarını, ikincisinde ise anne ve çocuğun beraber zor bir görevi (origami şekilleri) tamamlamasını istedik. Her biri 15'er dakika süren bu iki durumu video kameraya kaydedip, sonrasında Annelik Sicaklık ve Kontrol Ölçeği'ni (Maternal Warmth and Control Scale; Rubin ve Cheah, 2000; Rubin, Cheah ve Fox, 2001) kullanarak kodladık. Bu kodlama sistemine göre kayıtları 10'ar saniyelik dilimlere bölüp annelerin bu mikro-sürelerde çocuklarına gösterdikleri olumlu ve olumsuz kontrol, sıcaklık, duyarlılık, olumlu ve olumsuz duygulanım gibi davranışlarını ölçtük. Bu çalışmada ayrıca, annelere kendi ebeveynlik davranışlarını ve babaların ebeveynlik davranışlarını, babalara ise kendi ebeveynlik davranışlarını sorarak hem babaların hem de annelerin davranışları hakkında farklı kaynaklardan kapsamlı şekilde bilgi elde ettik (Yağmurlu, 2015). Bu araştırma, babaların ebeveynlik davranışlarını ölçen ve eşlerin birbirlerinin ebeveynlik davranışlarını değerlendirmesine, dolayısıyla bu davranışlar hakkında farklı kaynaklardan bilgi alınmasına, olanak sağlayan ender araştırmalardan biridir. Bu şekilde, tek bir kaynağa bağlı kalmak yerine, 
incelediğimiz gelişimsel mekanizmalar hakkında daha kapsamlı bilgi edinmemizi sağlayacak yöntemler kullanmış olduk.

Aşağıda özetlenen makalelerde de görüleceği gibi, araştırmalarımızda önem verdiğimiz noktalardan biri, tüm bu bahsedilen mekanizmaları, tipik gelişim gösteren çocukların yanı sıra, atipik gelişim gösteren çocuklarda da incelemek. Otizm spektrum bozukluğu tanısı almış çocuklar (örn., Yavuz, Selçuk ve Korkmaz, 2017a), işitme engeli olan çocuklar (örn., Alaylı ve Yağmurlu, 2015) ve ortopedik engeli olan çocuklar (örn., Yağmurlu ve Yavuz, 2015) araştırmalarımızda bu soruları incelediğimiz popülasyonlardan bazıları. Ayrıca, sadece tipik gelişim ortamında büyüyen çocuklarla çalışmak yerine, çocuk yetiştirme kurumunda yetişen çocuklar (örn., Etel ve Yağmurlu, 2015; Selçuk, Yavuz, Harma, Etel ve Ruffman, 2017; Selçuk ve Yücel, 2017) ve göçmenlik bağlamlarında hem Türkiye'de hem de yurt dışında (Avusturalya, Hollanda, Almanya) yetişen göçmen çocuklarla da araştırmalar yürütüyoruz (örn., Durgel, Leyendecker, Yağmurlu ve Harwood, 2009; Durgel, van de Vijver ve Yağmurlu, 2013; Ekmekci ve ark., 2015; Yağmurlu ve Sanson, 2009). Bu şekilde hem tipik gelişim gösteren hem de atipik özellikleri olan çocuklarda aynı gelişimsel mekanizmaların görülüp görülmediği, farklı unsurların farklı ortamlarda etkili olup olmadığını konusunda bilgi edinmeyi amaçliyoruz.

Bahsedilen tüm bu çalışmaların sonuçlarını bir arada ele aldığımızda, çocuklardaki psikolojik ve davranışsal çıktılar açısından iki becerinin önemli beceriler olarak belirdiğini söylemek mümkün. Bunlardan biri alıcı dil, diğeri ise yönetici işlev becerisi. Aşağıda bu becerileri farklı şekillerde ele alan araştırmalarımızın bulgularına yer veriyoruz.

\section{Alıcı Dil}

\section{Dil becerisi ve sosyal davranışlar}

Erken çocukluk döneminde dil becerisi hem eş zamanlı hem de ileri dönemlerdeki dil becerisinin, akademik başarının ve pek çok farklı sosyal ve bilişsel beceri ile psikososyal çıktının önemli bir yordayıcısıdır (örn., Hughes ve Ensor, 2008; Lee, 2011). Dil becerisi daha iyi olan çocuklar başkalarının zihinsel süreçlerinin kendilerininkinden farklı olabileceğini daha kolay anlayıp, başkalarının zihinsel süreçlerini kendi zihinlerinde daha kolay temsil edebilirler, yani daha yüksek bir zihin anlama becerisi (zihin kuramı) gösterirler (Astington ve Baird, 2005; Carlson, Mandell ve Williams, 2004). Dil becerisi ayrıca sözel yönergeleri anlamayı, bu yönergeleri içselleştirip gerekli durumlarda kendi kendine içsel konuşma ile bu yönergeleri tekrarlayıp davranışsal düzenlemeyi kolaylaştırır. Pek çok çalışma dil becerisi daha iyi olan 
çocukların öz-düzenleme becerisinin ve genel bilişsel becerilerinin de daha iyi olduğunu göstermiştir (örn., Carlson ve ark., 2004, Marchman ve Fernald, 2008). Dolayısıyla, küçük yaşlarda daha iyi dil becerisine sahip olmak, sonraki yıllardaki gelişimsel çıktılar için en kritik becerilerden biridir.

Dil gelişimini iki yönüyle ele alabiliriz. İlk olarak, kişinin kendisine yöneltilen dili anlaması, yani alıcı dil becerisi, ikincisi ise kişinin kendisinin dili kullanma becerisi, yani ifade edici dil becerisi. Alıcı dil becerisi, ifade edici dil becerisinden daha erken gelişir ve okul öncesi dönemdeki çocuklarda sosyal olarak olumlu davranışlar sergilemenin en belirgin öncüllerinden biri olarak ortaya çıkar (örn., Gertner, Rice ve Hadley, 1994). Okul öncesi dönemdeki tipik ve atipik gelişim gruplarında, dil becerisinin sosyal yetkinlik ve farklı sosyo-bilişsel kapasiteler ile bağlantılarını gösteren çok sayıda araştırma vardır.

Çocukların gelişimine en fazla etki eden faktörlerden biri yetiştirme bağlamıdır. Araştırmalar genellikle tipik olarak anne ve babaları ile ev ortamında yetişen çocuklara odaklanmıştır (örn., Hughes ve Ensor, 2011; Lane ve ark., 2013). Bunun yanında anne ve babaları olmayan (yetim veya öksüz) veya belirli sebeplerden dolayı ailesi olmasına rağmen kurumlarda yetişen çocuklar hemen tüm gelişimsel süreçlerde risk altındadır, gelişimleri genel olarak daha geriden gelir ve sosyal-duygusal problemler göstermeye daha yatkındırlar (Selçuk ve ark., 2017; Selçuk ve Yücel, 2017). Bu nedenle gelişim araştırmacılarının ve uygulamacıların eğilmesi gereken, ancak literatürde çok fazla incelenmemiş olan bir topluluk kurumlarda yetişen çocuklardır. Etel ve Yağmurlu (2015) tarafından Türkiye'deki dört farklı çocuk esirgeme kurumunda yetişen ve yaşları 3 ile 5 arasında değişen 107 çocuk ile yapılan kesitsel araştırmada, çocukların alıcı dil, zihin anlama (zihin kuramı) ve yönetici işlev becerilerinin sosyal yetkinliklerindeki rolü incelendi. Analizler, tüm değişkenler bir arada ele alındığında, sosyal yetkinliği en kuvvetle yordayan faktörün alıcı dil becerisi olduğunu ortaya koydu. Başka bir deyişle, kelime dağarcığı daha fazla olan çocukların, tüm diğer becerilerden bağımsız olarak, sosyal ilişkilerde daha iyi oldukları görüldü. Ayrıca alıcı dil becerisinin yönetici işlev ile doğrudan, zihin kuramı ile de dolaylı olarak bağlantılı olduğu, yani, alıcı dil becerisinin yönetici işlevi arttırarak dolaylı olarak zihin kuramını ilerlettiği bulundu. Dil, sosyal durumları ve bu durumların gerekliliklerini anlamak ve uygun şekilde davranmak (sosyal yetkinlik) için önemli bir beceridir. Bulgularımız, bu önermeyi doğrular niteliktedir (bkz., Hart, Newell ve Olsen, 2003).

Atipik başka bir popülasyon olan otizmli çocukların sosyal yetkinliğini incelediğimiz bir başka araştırma (Yavuz ve ark., 2017a) kapsamında, ortalama yaşı 8.5 olan otizm-spektrum bozukluğu tanısı almış 45 çocuk ile çalışıldı. Otizmde iletişim becerilerinin tümünde bir güçlük 
görüldüğünden, bu araştırma kapsamında sözel iletişimin yanı sıra sözel olmayan iletişim becerileri de ölçüldü ve sosyal yetkinlikle ilişkileri incelendi. Yine literatürde defaten gösterildiği üzere, otizmli çocuklar zihin anlama becerisinde sorun yaşarlar; ve dil ile birlikte zihin anlamada yaşadıkları güçlük sosyal becerilerini olumsuz etkiler (örn., Peterson, Slaughter ve Paynter, 2007). Bununla beraber, daha erken yaşlarda görülen ve zihin kuramının öncülü olarak görülen beceriler, örneğin zihinsel durumları anlama (örn., Yalnızca bir kutunun içine bakan kişinin o kutunun içinde ne olduğunu bilebileceğini, kutunun içine bakmayan kişinin içinde ne olduğunu bilemeyeceğini anlama) ve içsel durumları anlama (örn., Karda oynayan bir kişinin üşümüş olabileceğini anlama) becerileri, daha az çalışılmıştır. Bu araştırmada zihin kuramı ölçümünde bu daha basit bilişsel temsil becerileri incelendi. Bulgularımız, otizmli çocuklarda bilişsel temsil becerisi ile sözel ve sözel olmayan iletişim becerilerinin birbirleri ile pozitif ve anlamlı bağlantıları olduğunu ve bilişsel temsil becerisi kontrol edildiğinde dahi, sözel olmayan iletişim becerilerinin sosyal yetkinlik ile bağlantılı olduğunu gösterdi. Yani bulgular, sözel ve sözel olmayan iletişim becerileri arasında, otizmli çocuklarda sosyal yetkinlik ile ilişkili olan en önemli becerinin sözel olmayan iletişimi anlama ve sözel olmayan ifadeleri kullanabilme olduğunu ortaya çıkardı. Bu bulgular, jest ve mimikleri, el-kol-baş hareketlerini, işaret etmeyi ve genel olarak vücut dilini anlayıp kullanmanın otizmli çocukların sosyal gelişimine önemli etkisi olduğunu gösterdi.

Atipik gelişim gösterme ihtimali olan bir diğer popülasyon işitime engelli çocuklardır. Araştırmalar, işitme engelli çocukların işitme engeli olmayan çocuklara oranla sosyal ve bilişsel alanda daha fazla sorun yaşadıklarını (bkz., Hintermair, 2006), daha fazla saldırganlık ve daha düşük sosyal yetkinlik gösterdiklerini belirlemiştir (örn., Eldik, Treffers, Veerman, \& Verhulst, 2004; Wolters, Knoors, Cillessen, \& Verhoeven, 2011). Bu tip sorun davranışları etkileyen mekanizmaları incelediğimiz bir araştırmada, işitme engeli olan çocukların dil becerisinin zihin kuramını anlama, yönetici işlev, sosyal yetkinlik ve saldırganlık ile ilişkileri incelendi (Alaylı ve Yağmurlu, 2015). Bu araştırma yaşları 3 ile 12 arasında değişen 70 işitme engelli çocuk ile yapıldı. Tüm ölçekler işitme engelli çocuklara uygun olacak şekilde hazırlanıp uygulandı (örneğin, zihin kuramını ölçmek için sözel yükün az olduğu, görsel ağırlıklı bir zihin kuramı testi kullanıldı; de Villiers ve ve Villiers, 2012; Woolfe et al., 2002). Bulgular, yaş ve işitme engelinin şiddeti gibi değişkenler kontrol edildiğinde, alıcı dil becerisi (kelime bilgisi) daha iyi olan işitme engelli çocukların sosyal yetkinlik, zihin kuramı ve yönetici işlev becerilerinin daha yüksek olduğunu, saldırgan davranışları daha az gösterdiklerini ortaya koydu. Yönetici işlev ayrıca dil becerisi ve saldırganlık arasındaki ilişkide de aracı rol oynadı. Yani, alıcı dili daha iyi 
olan çocukların kendini denetleme becerileri de yüksek olduğundan daha az saldırganlık gösterdikleri bulundu.

Daha önce tipik gelişim gösteren çocuklarda dil ve yönetici işlev becerilerinin bağlantısı üzerine yapılmış çalışmalar, dil becerisinin mi öz-düzenlemeyi/yönetici işlevi yordadığı, yoksa yönetici işlevin mi dil becerisinin öncülü olduğunu kapsamlı şekilde tartışmıştır. Varılan sonuç her ikisinin de doğru olduğu, fakat dil becerisinden öz-düzenlemeye olan ilişkinin çok daha kuvvetli olduğu yönündedir (Botting ve ark., 2017). İşitme engelli çocuklar ile yapılan araştırmamız da literatürdeki bu bulgu ile uyumludur ve dil becerisinin öz-düzenlemenin en önemli yordayıcılarından biri olduğunu göstermektedir. Ayrıca, tüm bu araştırma sonuçlarımız, farklı popülasyonlardan farklı özelliklere sahip çocuklardaki sosyal davranış, yönetici işlev ve zihin kuramı gibi temel gelişimsel alanlar için dilin, özellikle alıcı dilin kritik olduğuna işaret etmektedir.

\section{Dil becerisini yordayan faktörler}

Dil becerisi ve kelime dağarcığı, sosyo-bilişsel beceriler ve sosyal ilişkiler için olduğu kadar, çocukların okuma-yazma becerileri ve okul başarıları için de kritik öneme sahiptir (Lee, 2011; Storch ve Witehurst, 2002). Alıcı dilin bu rolü, alıcı dili geliştiren unsurları anlamamızı gerektirir. Dil gelişimine baktığımızda, ilk yıldan itibaren bebeklerin dil becerisindeki farkların belirmeye başladığını görürüz (Fenson ve ark., 1994). Bu farklılığın oluşmasında hem bilişsel hem de sosyal-ilişkisel faktörler etkilidir (bkz., Hoff, 2006). Bilişsel faktörler arasında dil becerisi ile bağlantılı olan en önemli faktör yönetici işlev becerisi, yani işleyen bellek, dikkati düzenleme (dikkati gereken zamanlarda bir konu üzerinde tutabilme, gereken zamanlarda ise başka bir noktaya geçirebilme), ketleme ve planlamadan oluşan üst düzey bilişsel beceridir (ImBolter, Johnson ve Pascual-Leone, 2006). Bu bilişsel becerinin yanı sıra sosyal ilişkiler, özellikle de anne-çocuk ilişkileri ve duyarlı ebeveynlik, dil gelişimi için kritik öneme sahiptir. Duyarlı ebeveynlik ile ilgili literatüre bakıldığında duyarlı ebeveynliğin genellikle kapsamlı, tek bir değişken olarak ele alındığı görülür (örn., Cahill ve ark., 2007; Barry, Kochanska, ve Philibert, 2008; Paulussen-Hoogeboom, Stams, Hermanns, ve Peetsma, 2008). Fakat, duyarlı davranış farklı unsurlar içerir. Bunlardan biri ebeveyn davranışlarının duygusal boyutu, diğeri ise stimulasyon (uyarma) boyutudur. Duygusal boyuta odaklanan çalışmalar, çocuklarına sevgi gösteren, sarılan, öpen, ihtiyaçlarını karşılarken sıcak davranan, onları destekleyen annelerin çocuklarının kelime dağarcıklarının bu davranışları daha az gösteren annelerin çocuklarınınkine göre daha yüksek olduğunu göstermiştir (örn., Barnett, Gustaffson, Deng, Mills-Koonce ve Cox; 2012; Pungello, Iruka, Dotterer, Mills-Koonce ve Reznick, 2009; Tamis-LeMonda, 
Kuchirko ve Song, 2014). Duyarlı ebeveyn davranışlarının stimulasyon boyutu ile ilgili olarak ise en fazla incelenen davranış annelerin 'açıklayıcı akıl yürütme' davranışları, yani kural koyarken çocuklarına açıklamada bulunmaları, bir şeyin sebebini-sonucunu anlatmaları, sözel olarak çocuklarının davranışlarını yönlendirmeye çalışmalarıdır (Hoffman, 1979). Bu şekilde konuşma, çocuğun daha fazla dile maruz kalmasını sağlayarak dil gelişimini arttırmaktadır (Bannon, 2011).

Bunların tümü duyarlı ebeveynliğin unsurlarıdır. Fakat belirtildiği gibi, önceki araştırmalar duyarlılığın bu unsurlarını ayrıştırarak incelememiştir. Ekerim ve Selçuk (2017) makalesinde alıcı dile etki eden faktörler arasında hem çocukların bilişsel becerilerini (yönetici işlev) hem de annelerin duyarlı davranışlarını sıcaklık ve açıklayıcı akıl yürütme boyutlarını ayrıştırarak ölçtük. Ve bunların çocukların bir sene sonraki alıcı dil düzeyi ile bağlantısını araştırdık. Örneklemde ortalama yaşları 4.5 olan 239 çocuk yer aldı. Sonuçlar, çocukların ilk zamandaki yönetici işlev becerilerinin hem ilk zamandaki hem de bir sene sonra, yani ikinci zamandaki alıcı dil becerisini olumlu yönde yordadığını gösterdi. Bunun yanında, annelerin açıklayıcı davranışları dil becerisinin kuvvetli bir yordayıcısı olarak ortaya çıktı. İlk zamanda annelerinden daha çok açıklayıcı davranış gören çocukların bir sene sonraki kelime dağarcıklarının daha yüksek olması bu araştırmanın kritik bulgularındandır. Duyarlı ebeveynliğin bir başka alt başlığı olan sıcaklık gösterme ise çocukların dli gelişimi ile ilişkili bulunmadı. Başka bir deyişle, çalışma bulguları, annelerin çocuklarına açıklama yapmalarının, çocukları ile konuşmalarının önemini ortaya koydu.

Türkiye'deki anneler ile gerçekleştirilen önceki çalışmalar annelerin sıcaklık içeren fiziksel davranışları yaygınlıkla ve yüksek seviyede gösterdiklerini, yani çocuklarını sık sık öpüp okşayıp kucaklandıklarını, fakat çocukla az konuştuklarını göstermiştir (derleme için bkz., Şen, Yavuz ve Yağmurlu, 2015). Ekerim ve Selçuk (2017) makalesindeki bulgular bu 1şıkta ele alındığında, tipik bir Türk ailesinde çocukların sıcak bir aile ortamına rağmen, optimal gelişim için ideal koşullara sahip olmadıklarını söyleyebiliriz.

Ekerim ve Selçuk (2017) araştırmasındaki bir diğer önemli bulgu ise ailelerin sosyo-ekonomik düzeyi ile ilgili olandır. Buna göre, sosyo-ekonomik düzeyi (anne ve babanın eğitim ve geliri) daha yüksek olan ailelerin çocuklarının kelime dağarcığı daha gelişmiştir ve bu bağlantıda iki değişken aracı rol oynamaktadır: Annenin açıklayıcı davranışları ve çocuğun yönetici işlev becerisi. Bir başka deyişle, sosyo-ekonomik düzey yükseldikçe annelerin açıklayıcı davranışları artmakta, çocukların yönetici işlev becerisi ilerlemekte ve tüm bu unsurlar çocuğun dil gelişimini hızlandırmaktadır. Ekerim ve Selçuk araştırması, dezavantajı kesimlerden gelen, 
düşük eğitim veya gelire sahip ebeveynlerin çocuklarının pek çok gelişimsel çıktı bakımından neden daha geride olabileceklerine dair önemli ipuçları vermekte, bu çocukların okul başarısı dahil tüm alanlarda daha iyi durumda olmaları için okul öncesi dönemde nelere dikkat edilmesi gerektiğine dair önermede bulunmaktadır.

Sosyoekonomik düzeyin kelime dağarcığı üzerindeki önemi literatürde çok sayıda araştırma tarafından gösterilmektedir. Düşük ve yüksek sosyo-ekonomik düzeyden gelen çocukların kelime dağarcıkları karşılaştırıldığında, düşük sosyo-ekonomik düzeydeki ailelerde yetişen çocukların daha az kelime bilgisine sahip olduğu yaygınlıkla rapor edilen bir bulgudur (örn. Hart ve Risley, 1995). Stanford Üniversitesi'nden Prof. Anne Fernald'ın (2014) 5 yaşına geldiklerinde düşük ve yüksek sosyo-ekonomik düzeyden çocukların kelime dağarcıkları arasında 2 yıllık bir fark olduğunu ortaya koyan bulguları çarpıcıdır. Yani düşük sosyoekonomik düzeyden gelen 5 yaşındaki çocukların kelime bilgisi ancak 3 yaşındaki çocukların kelime bilgisine denktir. Bir diğer araştırma ise kelime dağarcığındaki bu uçurumun ilk yıllarda, 1,5 yaş civarı başladığını göstermektedir (Fernald, Marchman ve Weisleder, 2013). Buna göre 2 yaşında farklı sosyo-ekonomik düzeylerden gelen çocuklar arasında kelime dağarcığı bakımından 6 aylık bir fark vardır. Yani 2 yaşında yoksul bir çocuğun alıcı dil gelişimi orta veya yüksek gelire sahip ailelerin çocuklarının alıcı dil gelişiminden 6 ay daha geriden gelmektedir. Sebeplerine bakıldığında ise düşük sosyo-ekonomik düzeyden gelen çocukların 3 yaşına geldiklerinde yüksek gelir grubundan olan çocuklara kıyasla 30 milyon kelime daha az duymuş oldukları anlaşılmaktadır (Hart ve Risley, 2003). Daha ileriki yaşlarda çocukların duydukları kelime sayısındaki uçurum daha belirginleşmekte, bu farkın daha büyük yaşlarda 40-50 milyona çıktığı tahmin edilmektedir. Bununla bağlantılı olarak, orta sınıf ailelerin çocuklarının \%75'i okula hazır olarak başlamakta, yoksul ailelerin çocuklarında ise bu oran \%48 civarında kalmaktadır (Isaacs, 2012).

Çocuğun erken dönemdeki dil gelişimi için ebeveynin açıklama yapmasının, çocukla konuşmasının önemli olması ve bu ebeveyn davranışlarının etkisini hemen ilk yılda dahi gösteriyor olması dil uyarımının niteliğine dikkat çekiyor. Bu noktada şunu belirtmekte yarar var; çocuğun maruz kalabileceği dil iki şekilde olabilir, biri dolaylı olarak konuşmaya maruz kalma, yani başkaları konuşurken çocuğun da aynı ortamda bulunması ve bu konuşmalara maruz kalması, diğeri ise doğrudan maruz kalma, yani diğerlerinin çocuğa yönelik olarak konuşmasıdır. Düşük sosyo-ekonomik düzeyde hane halkı daha kalabalık olabildiğinden çocukların dile dolaylı olarak maruz kalmaları, yani başkalarının konuşmalarını daha fazla duymaları muhtemeldir. Fakat araştırmalar çocukların bu şekilde dolaylı olarak maruz 
kaldıkları konuşmadan çok daha az yarar gördüklerini, yeni kelimeleri bu tip ortamlarda daha yavaş öğrenebildiklerini, alıcı dil becerisini geliştiren en önemli stimulasyonun çocukla doğrudan konuşma olduğunu göstermektedir (Weisleder ve Fernald, 2013).

Ebeveynlik bilişleri, yani anne-babanın çocuk ve çocuğun gelişimine dair düşünceleri de buna etki eder. Rowe (2008) düşük sosyo-ekonomik düzeyden gelen anne-babaların çocuğun gelişimine yapabilecekleri katkıyı büyük ölçüde azımsadıklarını göstermiştir. Örgün eğitime az devam etmiş, düşük gelir grubundan ebeveynler, çocuğun dil ve bilişsel becerilerinin büyüme ve olgunlaşma ile beraber doğal olarak, kendiliğinden geliştiğini düşünmekte, bunları dışarıdan destekleme ile ilerleyecek alanlar olarak görmemektedir. Bu da beraberinde çocuğun gelişimini destekleyici davranışları göstermemeyi ve çocuğun dil becerilerinin daha yavaş gelişmesini getirmektedir.

Farklı sosyo-ekonomik düzeyden gelen ailelerdeki çocukların dil gelişimine etki eden faktörleri incelediğimiz bir başka çalışmada (Baydar ve ark., 2014), annelerin sıcak/duyarlı davranışlarının, annenin kelime dağarcığının, evdeki dili geliştirici uyaranların ve eğitici materyallerin ve annenin çocuk yetiştirme için aldığı desteğin 3 yaşındaki çocukların alıcı dil gelişimine etkilerine baktık. Bu araştırmanın güçlü yönlerinden biri Türkiye’yi temsil eden 1017 çocuktan oluşan bir örneklem kullanılmış olması idi. Bulgular, sosyo-ekonomik düzeyden bağımsız olarak, çocukların alıcı dil becerisinin annelerin kelime bilgisi ve evdeki eğitici materyallerin varlığı ile bağlantılı olduğunu gösterdi. Yani düşük ve yüksek sosyo-ekonomik düzeyde, benzer şekilde, bu değişkenler çocukların dil gelişimini anlamlı düzeyde yordadı. Analizler düşük ve yüksek sosyo-ekonomik düzeydeki aileler için ayrı ayrı yapıldığında ise bulgular, düşük sosyo-ekonomik düzeye sahip, yani eğitim ve gelir olarak daha dezavantajlı olan gruplarda, annenin depresif duygulanım hissetmediği durumda, sicak ve duyarlı ebeveynlik davranışlarının çocuğun dil becerisi ile bağlantılı olduğunu gösterdi. Başka bir deyişle, düşük sosyoekonomik düzeye sahip ailelerde anne depresyonda değilse olumlu annelik davranışları çocukların daha iyi dil becerilerine sahip olmaları ile ilintili idi. Öte yandan, düşük sosyoekonomik düzeye sahip ailelerde annenin depresif semptomlarının yüksek olduğu durumda, yani çifte risk durumunda, geniş aileden ve komşulardan gelen sosyal desteğin çocukların kelime dağarcığının önemli bir yordayıcısı olduğu belirlendi. Bu tür bir çifte riske sahip ailelerde anneler destek aldıklarında çocukların 3 yaşındaki kelime bilgilerinin daha fazla olduğu bulundu. Bu makale, sosyo-ekonomik düzeyin dil gelişimini nasıl etkilediğini (etki mekanizmaları) anlama konusunda Türkiye’ye özgü bir bulgu sunarak, gelişim modellerinin kültürel bağlama göre geliştirilebileceğine dair dikkate değer bir örnek ortaya koymaktadır. 


\section{Dil gelişimine erken müdahalenin önemi}

Erken çocukluktaki dil gelişiminin ileriki yaşlardaki sosyal ve bilişsel beceriler ile yakın bağlantısı, müdahale programlarının zamanlamasına dikkat çekiyor. Önceki araştırmalar ve müdahale çalışmaları, dil gelişimine ne zaman müdahale edilirse en iyi sonucun alındığı ile ilgili bilgi veriyor. Bu yazının başında da belirtildiği üzere, beyin gelişiminin çok önemli bir kısmı, yaklaşık \%90'1, çocuklar 5 yaşına gelmeden tamamlanmakta (Huttenlocher, 1994). Dil gelişimi ile ilgili beyin alanlarının ilk bir sene içinde çok önemli gelişim gösterdiği, beyindeki dil gelişimi ile ilgili bölgelerin plastisitenin bu dönemde yüksek olduğu bilinmekte (Kuhl, 2010). Dil gelişimi sonraki yıllarda devam etse de temelleri okul öncesi dönemde atılmakta ve gelişiminin önemli kısmı bu dönemde tamamlanmakta. Bu nedenle, özellikle ilk 1 yıl ve sonrasında okul öncesi dönem dil gelişimine müdahale için en önemli zaman olarak karşımıza çıkmakta.

Kısaca, hem Batı literatüründeki araştırmalar hem de Türkiye'deki örneklemlerden elde ettiğimiz sonuçlar, sosyal ve bilişsel gelişimi en kuvvetli şekilde yordayan becerilerden birinin alıcı dil (kelime dağarcığı) olduğunu gösteriyor. Alıcı dile becerisine etki eden unsurlara dair bilgimizin artması etkin müdahale programlarının geliştirilmesi bakımından önemli.

\section{Yönetici İşlev}

\section{Yönetici işlev ve sosyal davranışlar}

Dil becerisinin yanı sıra, erken dönemde gelişen diğer bir diğer kritik beceri ise yönetici işlev. Yönetici işlev, kendini denetleme, öz-düzenleme, işleyen bellek, plan yapma, ketleme, kendini denetleme gibi becerilerden oluşan üst düzey bir bilişsel beceridir. Dil becerisine göre yönetici işlevin gelişimi biraz daha geç başlar; yönetici işlevden sorumlu beyin bölgelerinin plastisitesi daha yüksektir ve yönetici işlev becerisi daha ileriki yıllarda da kayda değer bir gelişim gösterir. Literatürdeki araştırmalar yönetici işlev becerisinin çocukların sosyal gelişimi ile yakından ilişkili olduğunu ortaya koymaktadır. Yönetici işlev özellikle davranışsal regülasyon (davranış düzenleme) problemi içeren şiddet, akran zorbalığı, saldırgan davranışlar bağlamında sıklıkla incelenmiş, saldırganlık ve davranım bozukluğu gösteren çocuklarda yönetici işlevde güçlük olduğu saptanmıştır (Hughes ve Ensor, 2011; Seguin ve Zelazo, 2005). Türkiye'deki okul öncesi yaş çocuklarıyla yapılan araştırmalar da yönetici işlev becerisinin dışa yönelim problemlerini arttırdığını göstermektedir. Ortalama yaşı 4.5 olan okul öncesi dönemdeki 212 çocuk ile gerçekleştirilen bir araştırmamız (Korucu, Selçuk, ve Harma, 2017) ile 3 ila 5 
yaşlarındaki 118 çocuk ile yaptığımız bir başka araştırmamız (Orta, Çorapçı, Yağmurlu ve Aksan, 2013) buna birer örnektir.

Araştırmalar (örn., Hughes ve Ensor, 2011; ayrıca bkz., Liew, 2012) yönetici işlev becerisinin, dışa yönelim sorunlarının yanı sıra içe yönelim sorunlarını azalttığını gösterse de, bu araştırmalar sayıca daha azdır ve yönetici işlevin çocuklardaki sosyal ve duygusal yetkinlik ile bağlantısı daha az bilinmektedir. Araştırmalarımızda yönetici işlevin dışa yönelim sorunları ile bağlantılarının yanı sıra, çocuklardaki sosyal yetkinlik, sosyal çekiniklik ve içe yönelim sorunları gibi problem davranışları ile bağlantılarını da inceledik. Bunun yanında, yönetici işleve etki eden faktörleri araştırdık. Bulgularımız yönetici işlevin çocuklardaki sosyal yetkinlikte de rolü olduğunu, yönetici işlev becerisinde sorun yaşayan çocukların sosyal durumlarda daha fazla zorlandıklarını gösterdi (Korucu ve ark., 2017; Orta ve ark., 2013). Türkiye'nin farklı 5 ilinden okul öncesi dönemdeki (37-73 aylık) 217 çocuk ile yaptığımız bir araştırmada (Gündüz, Yağmurlu ve Harma, 2015) hem yönetici işleve etki eden faktörleri, hem de yönetici işlevin sosyal-duygusal yetkinlik üzerindeki rolünü inceledik. Yönetici işleve etki eden faktörler arasında annelerin depresif duygulanımları ile duyarlı ve güç gösterimine dayalı ebeveynlik davranışlarının rolü ölçüldü. Bulgular, annede duyarlılığın düşük, güç gösteriminin yüksek olduğu durumlarda çocuğun yönetici işlev gelişiminin daha geride olduğunu gösterdi. Annenin depresif hislerinin yüksek olması da duyarlılığı azaltıp güç gösterimini arttırarak dolaylı yoldan çocukların yönetici işlevinin daha düşük olması ile ilişkili bulundu. $\mathrm{Bu}$ araştırmada, yönetici işlevin bağlantısının incelendiği sosyal-duygusal yetkinliğin ölçümünde anne bildirimi, öğretmen bildirimi ve çocuklar ile yapılan bireysel değerlendirmelerden yararlanıldı. Sonuçlar, yüksek yönetici işlev becerisine sahip çocukların sosyal-duygusal olarak daha yetkin olduklarını gösterdi. Ayrıca annenin depresif duygulanımı güç gösterimine dayalı ebeveynlik davranışlarını arttırıp çocuğun yönetici işlev beceri gelişimini yavaşlatarak sosyalduygusal yetkinliğinin daha düşük olmasını yordadı. Bu bulgu, ebeveynin psikolojik esenliğinden ve davranışlarından sosyal-duygusal yetkinliğe uzanan yoldaki aracı mekanizmanın yönetici işlev olduğunu ortaya koydu.

Okul öncesi (3-5 yaş) dönemdeki 118 çocuk ile yaptığımız bir başka araştırmada (Orta ve ark., 2013) annenin duyarlı davranışları ve çocuğun yönetici işlev becerisinin dışa yönelim sorunlarının yanı sıra sosyal-duygusal yetkinlikteki rollerini inceledik. Araştırmanın sonuçları, ebeveyni daha duyarlı olan çocukların yönetici işlev becerisinin daha ileri olduğunu ve bunun da dolaylı olarak daha düşük duygu düzenleme güçlügünü ve daha yüksek sosyal yetkinliği 
yordadığını gösterdi. Ayrıca daha önce bahsedildiği gibi daha ileri yönetici işlev becerileri olan çocukların daha az dışa yönelim sorunları gösterdikleri belirlendi.

Yönetici işlevin davranışsal çıktılar üzerine etkisine bakıldığında, literatürde çok az incelenmiş bir alanın çocuklardaki sosyal uzaklaşma davranışları olduğunu görürüz. Yakın zamanda yaptığımız bir diğer araştırma (Selçuk ve ark., 2017) bu bağlantıyı kurumda yetişen çocuklarda inceledi. Yetimhane gibi yetiştirme kurumlarında büyüyen çocuklar, hem küçük yaşlarda hem de ileriki yaşlarda yalnızlık, depresyon, kaygı gibi duygu-durum problemlerini daha fazla yaşayabilmekte, daha fazla intihar eğilimi gösterebilmektedir (Almas ve ark., 2015; Burkholder, Koss, Hostinar, Johnson ve Gunnar, 2016; Hawk ve McCall, 2011; Tottenham ve ark., 2010). Bu sebeple, bu çocuklarda içe yönelim sorunları ile hangi gelişimsel çıktıların ilintili olduğunu araştırmak hem kavramsal olarak hem de uygulamadaki önemi bakımından gereklidir. Bu araştırma (Selçuk ve ark., 2017) kapsamında, bir yıl ara ile SHÇEK'e bağlı yetiştirme kurumlarında yaşayan çocuklardaki yönetici işlev, zihin kuramı ve alıcı dil (kelime haznesi) ölçüldü ve bu becerilerin bir sene sonraki sosyal uzaklaşma davranışındaki rolleri incelendi. Bulgular, alıcı dil becerisinin yönetici işlevin önemli bir yordayıcısı olduğunu, alıcı dili yüksek olan çocukların yönetici işlev becerilerinin de daha ileri olduğunu gösterdi. Bunun yanında, ikinci zamanda ölçülen sosyal uzaklaşma davranışlarının en kuvvetli yordayıcısının yönetici işlev olduğu bulundu. Birinci zamanda daha yüksek yönetici işlev becerisi, ikinci zamandaki yönetici işlevi yordayarak, bu aracı mekanizma üzerinden, dolaylı olarak, sosyal uzaklaşma davranışının daha az olması ile bağlantı gösterdi. $\mathrm{Bu}$ bir yıllık boylamsal araştırmanın bulguları, bakıcı-çocuk oranı, çocuğun yaşı, cinsiyeti, kuruma gelme yaşı, kurumda yaşama süresi, zihin kuramı ve çok önemli olduğunu bildiğimiz alıcı dil becerisi kontrol edildikten sonra da yönetici işlevin sosyal uzaklaşmayı kuvvetle yordadığını gösterdi.

Yönetici işlev ve zihin kuramı, okul öncesi dönemde önemli gelişim gösteren ve sosyal davranışların anlamlı birer yordayıcısı olarak literatürde sıkça incelenen iki temel beceridir. Yönetici işleve benzer şekilde zihin kuramının (zihin anlama) düzeyi de sosyal davranışlar için kritiktir (Astington, 2003). 2-12 yaş arasındaki çocuklarla yapılan 76 araştırmanın bulgularının derlenerek incelendiği meta-analiz çalışması zihin kuramı becerisi yüksek olan çocukların daha fazla olumlu sosyal davranış gösterdiklerini ortaya koyuyor (Imuta, Henry, Slaughter, Selçuk ve Ruffman, 2016). Zihin kuramı ve yönetici işlevin birbiri ile de güçlü ilişkisi olduğu da pek çok çalışma tarafından ortaya konan bir bulgu (Carlson, Mandell ve Williams, 2004; Carlson, Moses ve Breton, 2002; Hughes, 1998; Müller, Liebermann-Finestone, Carpendale, Hammond ve Bibok, 2012). Ancak hangi becerinin diğerinin öncülü olduğu kesin değil. Bulgulardan 
bazıları zihin kuramının yönetici işlevin öncülü olduğunu gösterirken (örn., Marcovitch ve ark., 2015; Müller ve ark., 2012; Perner ve Lang, 2000), diğerleri yönetici işlevin belirleyici olduğunu önermekte (örn., Carlson ve ark., 2004; Razza ve Blair, 2009). Literatürde her iki önermeye de destek veren sonuçlar var. Ancak önemli bir bulgu, okul öncesi dönemdeki çocuklarla yapılmış 102 araştırmanın sonuçlarını içeren bir meta-analiz çalışması (Devine ve Hughes, 2014) tarafindan ortaya konuyor. Buna göre, öncül olan yönetici işlev becerisi. Koç Üniversitesi Çocuk ve Aile Çalışmaları Laboratuvarı'nda yakın zamanda tamamladığımız araştırmalardan biri de bu konu üzerine. Türkiye'deki okul öncesi dönemdeki 150 çocuk ile yaptığımız bu araştırmada yönetici işlev ve zihin kuramı becerilerini bir yıl ara ile ölçerek, kesitsel ve boylamsal bağlantılarını inceledik (Doenyas, Yavuz ve Selçuk, 2018). Ve önceki araştırmalardan farklı olarak, bu çalışma kapsamında, zihin kuramı becerisini tek unsuru olan homojen bir bilişsel beceri olarak ele almadık, zihin kuramının farklı unsurlarını değerlendiren, Wellman ve Liu (2004) tarafından geliştirilen kapsamlı bir zihin kuramı ölçüm bataryası kullandık. Araştırmanın sonuçları, çocukların yaşı kontrol edildikten sonra yönetici işılev becerisinin zihin kuramını hem eş zamanlı olarak hem de bir sene sonra, boylamsal olarak yordadığını gösterdi. Zihin kuramı ise yönetici işlev becerisini yordamadı. Bu bulgu, sadece zihin kuramının "yanlış inanışı anlama" unsuru için anlamlı bulundu, zihin kuramı bataryası kapsamında incelenen diğer unsurlar (farklı istek, farklı inanış, bilgi erişimi) için bu ilişki istatistiksek olarak anlamlı değildi. Bu literatüre katkı yapan bir bulgudur.

Özetle söylemek gerekirse, Türkiye'deki farklı örneklemlerle yaptığımız araştırmalar, yönetici işlevin saldırganlık gibi dışa yönelim problemlerinin yanı sıra, sosyal uzaklaşma gibi içe yönelim problemleri ve sosyal yetkinlikle de ilintili olduğunu, annelik davranışlarının, özellikle güç gösterimi ve duyarlılığın yönetici işlev gelişiminde rolü olduğunu gösterdi.

\section{Yönetici işleve müdahale}

Yukarıda özetlediğimiz araştırma sonuçlarının da gösterdiği üzere, yönetici işlev pek çok davranışsal, sosyal ve bilişsel beceri ile ilişkilidir. Ancak yönetici işlev becerisinin kritik işlevini en iyi ortaya koyan çalışmalardan biri Moffitt ve arkadaşları (2010) tarafindan Yeni Zelanda'da yapılan ve 1000 kişiyi doğumdan itibaren kırk küsur yıl takip eden boylamsal araştırmadır (the Dunedin Study). Bu çalışmanın bulguları yönetici işlev becerisinin hayatın her alanındaki olumlu çıktı ile bağlantılı olduğunu, çocukluk çağında yüksek yönetici işleve sahip olan kişilerin 32 yaşına geldiklerinde hem psikolojik hem de fiziksel olarak daha sağlıklı, maddi olarak daha refah içinde olduklarını ve daha az kriminal davranış gösterdiklerini ortaya koymuştur 
$\mathrm{Bu}$ bulgular, yönetici işlev becerisini geliştirmeyi hedefleyen müdahale çalışmalarından alınacak faydanın yüksek olacağını önermektedir. Yönetici işlevden sorumlu yapılar (prefrontal korteks) beynin en geç gelişen bölgelerindendir. Bu bölgeler, ilk yaş içerisinde, 7-8. aydan itibaren gelişmeye başlayıp, en hızlı gelişimini ilk 6-7 yaşa kadar gösterir (Garon, Bryson ve Smith, 2008; Zelazo, Craik ve Booth, 2004). Bu beyin bölgelerinin plastisitesi daha fazla olduğundan, yönetici işlev becerisini geliştirmeyi hedefleyen çalışmaların etkin olacağı yaş aralığı da daha geniştir. Bu amaçla geliştirilen pek çok farklı müdahale programı vardır (bkz., Diamond ve Lee, 2005). Bu çalışmalar içerisinde en etkili olanlar çocukların fiziksel egzersizler yapmalarını içeren programlardır. Sibley ve Etnier (2003) tarafından yapılan ve 44 araştırmayı inceleyen meta-analiz çalışmasının sonuçları da fiziksel aktivitenin çocukların bilişsel kontrol becerilerini geliştirdiğini göstermiştir ve bu etkinin istatistiksel gücü yüksektir (etki büyüklüğü = .32). Dahası, bu çalışma fiziksel aktivite yapmanın içerikten bağımsız olarak, yönetici işlev becerisini olumlu etkilediğini ve fiziksel etkinliğin bilişsel gelişime etkisinin en fazla 4-7 (etki büyüklügü = .40) ve 11-13 (etki büyüklügü = .48) aralığındaki yaş gruplarında olduğunu göstermiştir. Kurumda yaşayan çocukların bilişsel becerilerini geliştirmeyi hedefleyen müdahale programları üzerine yapılan bir meta-analiz çalışması (BakermansKranenburg, Van IJzendoorn ve Juffer, 2008) da daha erken yaşta yapılan müdahale çalışmalarının daha etkili olduğunu ortaya koymuştur (toplam etki büyüklüğü $=.84 ; 1$ yaşından önce gerçekleşen müdahale programları için etki büyüklüğ̈̈=1.03).

Davranışsal iktisatçılar ve politika yapıcılar için önemli bir bulgu da müdahale programlarının ekonomik değeridir. Heckman (2006) insana yapılan eğitimsel yatırımın ekonomik karşılığının en çok okul öncesi dönemde alındığı göstermiştir. Yani aynı eğitim veya iyileştirme çalışması (müdahale) okul öncesi dönemde yapıldığı zaman kişide yarattığ 1 fark okul dönemi ve yetişkinlikte yapılana göre çok daha fazladır. Tüm bu bilgiler okul öncesi yaşların müdahale için en uygun dönem olduğuna işaret etmektedir.

Çağımızda bilişsel kontrol becerisine olan ihtiyaç giderek artmakta. İngilizcede 'multi-tasking' diye geçen, aynı anda birden fazla iş yapma gibi yönetici işlev kullanımını gerektiren durumlar giderek yaygınlaşıyor ve çocukların günlük hayatında dahi yaygın hale geliyor. Örneğin, televizyon izlerken bir yandan telefondan mesaj yazmak vb. dikkati bölme, yöneltme, davranışların bazılarını ketleyip bazılarını aktive etme gibi becerileri, dolayısıyla yönetici işlevi etkin olarak kullanmayı gerektiriyor. Hayat bir yandan bu yönde ilerlerken, bir yandan yaşamın hızı, yapılması gereken işlerin sayısı vb. kişinin stres düzeyini arttırıyor. Ve stres, bilişsel kontrol becerilerini olumsuz etkilediği bilinen faktörlerin başında geliyor. Deneyler, anne 
farelerin hamileliğin son döneminde strese maruz kalması durumunda bebek farelerin duygu kontrolünden sorumlu beyin bölgeleri (cingulate kortex ve orbitofrontal cortex) arasında daha az nöral bağlantı görülüğünü ortaya koyuyor (örn., Bock, Breuer, Poeggel ve Braun, 2017; Gröger ve ark., 2016). İnsanlarla yapılan çalışmalar da küçük yaşta aileden ayrı kalma ve uzun süren aşırı yoksulluk gibi psikolojik travmaların beyindeki stres düzenlemeden sorumlu bölgelerde bozulmaya yol açtığını gösteriyor (Oberlander ve ark., 2008; Tyrka ve ark., 2012). Günümüzde, çocuk veya yetişkin, bir insanın hayat temposu, iş yükü, aynı anda birden çok iş yapma alışkanlığının yaygınlaşması ve artan stres düşünüldüğünde, dikkat, duygu ve davranış regülasyonunun giderek ne kadar elzem olduğu ve dolayısıyla yönetici işlev becerisinin işlevinin daha da önemli olduğu ortaya çıkıyor.

\section{SONUÇ}

Sonuç olarak Türkiye'de farklı örneklem grupları ile farklı yöntemler kullanarak yaptığımız araştırmalar, Batılı örneklemlerden elde edilen bulgularla uyumlu olarak, alıcı dil ve yönetici işlev becerilerinin optimal bir bilişsel ve sosyal gelişim için kritik olduğunu gösteriyor. Yazımızın başında da belirttiğimiz üzere, anne-çocuk ilişkisinin olumlu olduğu durumlarda çocuğun gelişimsel sonuçlarının ve esenliğinin iyi olduğu bilinmekte. Fakat esas önemli olan bu etkilerin neden ve nasıl olduğunu, mekanizmalarını ortaya çıkarmak, anlamak. Bu makalede sosyo-ekonomik düzey gibi en geniş demografik özelliklerden, ebeveynin psikolojik esenliğine, çocuk yetiştirme davranışlarına, çocukların kendi gelişimsel becerilerinin rolüne kadar pek çok farklı unsurun nasıl etkileşim içerisinde çocuk gelişimiyle, bazen alıcı dil, bazen yönetici işlev, zihin kuramı ve bazen sosyal davranışlarla bağlantılı olduğunu gösterdik. İlgili araştırmalarımızın sonuçlarını literatürle bağlantılandırarak anlatmaya gayret ettik. Mevcut bilgimiz, özellikle okul öncesi dönemde eğitim müfredatına kelime haznesi ve yönetici işlevi geliştirici etkinliklerin eklenmesinin hem eş zamanlı olarak hem de uzun dönemde bireyin gelişimini ve esenliğini olumlu yönde etkileyeceğini öneriyor. Bu gibi kavramsal bilgiler uygulamada yer bulduğunda yararları kat kat artar. Psikoloji ve eğitim disiplinleri, bu bilgilerin ortaya konması ve uygulanması hedeflerinde kesişirler.

\section{KAYNAKÇA}

Alaylı, A., \& Yağmurlu*, B. (2015, Mart). Sequential development of theory of mind and the role of social pretence in Turkish children with hearing impairment. Society for Research in Child Development Biennial Meeting (SRCD) Poster sunumu. 
Philadelphia, USA.

Almas, A. N., Degnan, K. A., Walker, O. L., Radulescu, A., Nelson, C. A., Zeanah, C. H., \& Fox, N. A. (2015), The effects of early institutionalization and foster care intervention on children's social behaviors at the age of eight. Social Development, 24, 225-239.

Astington, J. W. (2003). Sometimes necessary, never sufficient: False-belief understanding and social competence. In B. Repacholi \& V. Slaughter (Eds.), Individual differences in theory of mind: Implications for typical and atypical development (pp. 13-38). New York: Psychology Press.

Astington, J. W., \& Baird, J. A. (2005). Introduction: Why language matters. In J. W. Astington \& J. Baird (Eds.), Why language matters for theory of mind (pp. 3-25). New York, NY: Oxford University Press.

Bakermans-Kranenburg, M. J., van IJzendoorn, M. H., \& Juffer, F. (2008). Earlier is better: A meta-analysis of 70 years of intervention improving cognitive development in institutionalized children. Monographs of the Society for Research in Child Development, 73(3), 279-293.

Bannon, R. S. (2011). Inductive parenting. In S. Goldstein \& J. A. Naglieri (Eds.), Encyclopedia of child behavior and development (pp. 807-808). Boston, MA: Springer.

Barnett, M. A., Gustafsson, H., Deng, M., Mills-Koonce, W. R., \& Cox, M. (2012). Bidirectional associations among sensitive parenting, language development, and social competence. Infant and Child Development, 21, 374-393.

Barry, R. A., Kochanska, G., \& Philibert, R. A. (2008). G X E interaction in the organization of attachment: Mothers' responsiveness as a moderator of children's genotypes. Journal of Child Psychology and Psychiatry, 49, 1313-1320.

Baydar, N., Küntay, A., Yagmurlu, B., Aydemir, N., Cankaya, D., Gökşen, F., \& Cemalcilar, Z. (2014). "It takes a village" to support the vocabulary development of children with multiple risk factors. Developmental Psychology. 50(4), 1014-1025.

Bock, J., Breuer, S., Poeggel, G., \& Braun, K. (2017). Early life stress induces attention-deficit hyperactivity disorder (ADHD)-like behavioral and brain metabolic dysfunctions: Functional imaging of methylphenidate treatment in a novel rodent model. Brain Structure and Function, 222(2), 765-780. 
Botting, N., Jones, A., Marshall, C., Denmark, T., Atkinson, J. \& Morgan, G. (2017).Nonverbal execute function is mediated by language: A study of deaf and hearing children. Child Development, $88,1689-1700$.

Brumariu, L. E. ve Kerns, K. A. (2011). Parent-child attachment in early and middle childhood. In P. K. Smith \& C. H. Hart (Eds.), Wiley-Blackwell handbook of childhood social development, 2nd ed. (pp. 227-245). West Sussex, UK: Wiley-Blackwell.

Burkholder, A. R., Koss, K. J., Hostinar, C. E., Johnson, A. E., \& Gunnar, M. R. (2016). Early life stress: effects on the regulation of anxiety expression in children and adolescents. Social Development, 25, 777-793.

Cahill, K. R., Deater-Deckard, K., Pike, A., \& Hughes, C. (2007). Theory of mind, self-worth and the mother-child relationship. Social Development, 16, 45-56.

Caldji, C., Tannenbaum, B., Sharma, S., Francis, D., Plotsky, P. M., \& Meaney, M. J. (1998). Maternal care during infancy regulates the development of neural systems mediating the expression of fearfulness in the rat. Proceedings of the National Academy of Sciences, 95(9), 5335-5340.

Carlson, S. M., Mandell, D. J., \& Williams, L. (2004). Executive function and theory of mind: Stability and prediction from ages 2 to 3. Developmental Psychology, 40, 1105-1122.

Carlson, S. M., Moses, L. J., \& Breton, C. (2002). How specific is the relation between executive function and theory of mind?Contributions of inhibitory control and working memory. Infant and Child Development, 11, 73-92.

Cassidy, J. (2008). The nature of child's ties. In J. Cassidy \& P. R. Shaver (Eds.) Handbook of attachment: Theory, research, and clinical applications (2nd Ed). (pp. 3-22). NY: The Guilford Press.

Charpak, N., Ruiz-Peláez, J. G., Figueroa de Calume, Z., \& Charpak, Y. (2001). A randomized, controlled trial of kangaroo mother care: Results of follow-up at 1 year of corrected age. Pediatrics, 108(5), 1072-1079.

DeKlyen, M., \& Greenberg, M.T. (2008). Attachment and psychopathology in childhood. In J. Cassidy \& P.R. Shaver (Eds.), Handbook of attachment: Theory, research and clinical applications (2nd ed.). New York, NY: Guildford Press. 
de Villiers, P., \& de Villiers, J.G. (2012). Deception dissociates from false belief reasoning in deaf children: Implications for the implicit versus explicit theory of mind distinction. British Journal of Developmental Psychology, 30, 188-209

Devine, R. T., \& Hughes, C. (2014). Relations between false belief understanding and executive function in early childhood: A meta-analysis. Child Development, 85, 1777-1794.

Diamond, A., \& Lee, K. (2011). Interventions shown to aid executive function development in children 4 to 12 years old. Science, 333(6045), 959-964.

Doenyas, C., Yavuz, M., \& Selçuk, B. (2018). Executive function predicts theory of mind and relates mainly to knowledge access and false belief understanding in Turkish preschool children Journal of Experimental Child Psychology, 166, 485-501.

Durgel, E., Leyendecker, B., Yağmurlu*, B., \& Harwood, R. (2009). Sociocultural influences on German and Turkish immigrant mothers' long-term socialization goals. Journal of Cross-Cultural Psychology, 40, 834-852.

Durgel, E., van de Vijver, F. J. R., \& Yağmurlu*, B. (2013). Self-reported maternal expectations and child-rearing practices: Disentangling the role of ethnicity, immigration, and educational background. International Journal of Behavioral Development, 37, 35-43.

Ekerim, M., \& Selcuk, B. (2017). Longitudinal predictors of vocabulary knowledge in Turkish children: The role of sensitive parenting and executive functions. Early Education and Development. Online yayım: 11 Aralık 2017. doi: 10.1080/10409289.2017.1407607

Ekmekci, H., Yavuz, M., Emmen, R., Mesman, J., Van IJzendoorn, M., Yağmurlu*, B., \& Malda, M. (2015). Professionals' and mothers' beliefs about maternal sensitivity across cultures: Toward effective interventions in multicultural society. Journal of Child and Family Studies, 24, 1295-1306.

Eldik, V.T., Treffers, P.D., Veerman, J.W., \& Verhulst, F.C. (2004). Mental health problems of deaf Dutch children as indicated by parents' responses to the child behavior checklist. American Annals of the Deaf, 148, 390-395.

Etel, E., \& Yağmurlu*, B. (2015). Social competence, theory of mind, and executive function in institution-reared Turkish children. International Journal of Behavioral Development, 39(6), 519-529. 
Fenson, L., Dale, P. S., Reznick, J. S., Bates, E., Thal, D. J., \& Pethick, S. J. (1994). Variability in early communicative development. Monographs of the Society for Research in Child Development, 59, Serial No. 242.

Fernald, A. (2014). How talking to children nurtures language development across SES and culture. Symposium American Association for the Advancement of Science, Chicago: USA.

Fernald, A., Marchman, V. A. \& Weisleder, A. (2013). SES differences in language processing skill and vocabulary are evident at 18 months. Developmental Science, 16(2), 234-248.

Garon, N., Bryson, S. E. \& Smith, I. M. (2008). Executive function in preschoolers: A review using an integrative framework. Psychological Bulletin, 134, 31-60.

Gertner, B. L., Rice, M. L., \& Hadley, P. A. (1994). Influence of communicative competence on peer preferences in a preschool classroom. Journal of Speech and Hearing Research, 37, 913-923.

Goldsmith, H. H., \& Rothbart, M. K. (1996). The Laboratory Temperament Assessment Battery (Lab-TAB): Locomotor version 3.0. Technical manual, Department of Psychology, University of Wisconsin, Madison, WI.

Gröger, N., Matas, E., Gos, T., Lesse, A., Poeggel, G., Braun, K., \& Bock, J. (2016). The transgenerational transmission of childhood adversity: behavioral, cellular, and epigenetic correlates. Journal of Neural Transmission, 123(9), 1037-1052.

Gülseven, Z., Carlo, C., Streit, C., Kumru, A., Selcuk, B., \& Sayil, M. (2017). Longitudinal relations among parenting daily hassles, child rearing, and prosocial and aggressive behaviors in Turkish children. Social Development. Online yayım: 16 Mayıs 2017. doi: $10.1111 /$ sode. 12247

Gündüz, G., Yağmurlu*, B., \& Harma, M. (2015). Self-regulation mediates the link between family context and socioemotional competence in Turkish preschoolers. Early Education and Development, 26, 729-748.

Hart, C. H., Newell, L. D., \& Olsen, S. (2003). Parenting skills and social-communicative competence in childhood. In J. O. Greene, B. R. Burleson, J. O. Greene \& B. R. Burleson (Eds.), Handbook of communication and social interaction skills (pp. 753-797). Mahwah, NJ: Lawrence Erlbaum. 
Hart, B., \& Risley, T. R. (1995). Meaningful differences in the everyday experience of young American children. Baltimore: Paul H Brookes Publishing.

Hart, B., \& Risley, T. R. (2003). The early catastrophe: The 30 million word gap by age 3. American Educator, 27(1), 4-9.

Hawk, B.N., \& McCall, R.B. (2011). Specific extreme behaviors of post institutionalized Russian adoptees. Developmental Psychology, 47, 732-738.

Heckman, J. J. (2006). Skill formation and the economics of investing in disadvantaged children. Science, 312, 1900-1902.

Hintermair, M. (2006). Parental resources, parental stress, and socioemotional development of deaf and hard of hearing children. Journal of Deaf Studies and Deaf Education, 11, 493513.

Hoff, E. (2006). How social contexts support and shape language development. Developmental Review, 26, 55-88.

Hoffman, M. L. (1979). Development of moral thought, feeling, and behavior. American Psychologist, 34, 958-966.

Hughes, C. (1998). Finding your marbles: Does preschoolers' strategic behavior predict later understanding of mind? Developmental Psychology, 34, 1326-1339.

Hughes, C., \& Ensor, R. (2008). Does executive function matter for preschoolers' problem behaviors. Journal of Abnormal Child Psychology, 36, 1-14.

Hughes, C, \& Ensor, R. (2011). Individual differences in growth in executive function across the transition to school predict externalizing and internalizing behaviors and selfperceived academic success at 6 years of age. Journal of Experimental Child Psychology, 108, 663-676.

Harlow, H. F., \& Harlow, M. K. (1962). Social deprivation in monkeys. Scientific American, 207, 136-146.

Huttenlocher, P. R. (1994). Synaptogenesis in human cerebral cortex. In G. Dawson \& K. W. Fischer (Eds.), Human behavior and the developing brain. New York: Guilford Press.

Im-Bolter, N., Johnson, J., \& Pascual-Leone, J. (2006). Processing limitations in children with specific language impairment: The role of executive function. Child Development, 77, $1822-1841$. 
Imuta, K., Slaughter, V., Henry, J., Selçuk, B., \& Ruffman, T. (2016). Theory of mind and prosocial behavior in childhood: A meta-analytic review. Developmental Psychology, 52(8), 1192-1205

Isaacs, J. B. (2012). Starting School at a Disadvantage: The School Readiness of Poor Children. The Social Genome Project. Center on Children and Families at Brookings, 1-22.

Kochanska, G. (1998). Mother-child relationship, child fearfulness, and emerging attachment: A short-term longitudinal study. Developmental Psychology, 34, 480-490.

Korucu, I., Selçuk, B., \& Harma, M. (2017). Self-regulation: Relations with theory of mind and social behaviour. Infant and Child Development, 26 (3).

Kuhl P. K. (2010). Brain mechanisms in early language acquisition. Neuron 67, 713-727

Lane, J. D., Wellman, H. M., Olson, S. L., Miller, A. L., Wang, L., \& Tardif, T. (2013). Relations between temperament and theory of mind development in the United States and China: Biological and behavioral correlates of preschoolers' false-belief understanding. Developmental Psychology, 49, 825-836.

Lee, J. (2011). Size matters: Early vocabulary as a predictor of language and literacy competence. Applied Psycholinguistics, 32, 69-92.

Liew, J. (2012). Effortful control, executive functions, and education: Bringing self-regulatory and social-emotional competencies to the table. Child Development Perspectives, 6, $105-111$.

Mathuru, A. S., Kibat, C., Cheong, W. F., Shui, G., Wenk, M. R., Friedrich, R. W., \& Jesuthasan, S. (2012). Chondroitin fragments are odorants that trigger fear behavior in fish. Current Biology, 22(6), 538-544.

Marcovitch, S., O’Brien, M., Calkins, S. D., Leerkes, E. M., Weaver, J. M., \& Levine, D. W. (2015). A longitudinal assessment of the relation between executive function and theory of mind at 3, 4, and 5 years. Cognitive Development, 33, 40-55.

Marchman, V. A., \& Fernald, A. (2008). Speed of word recognition and vocabulary knowledge in infancy predict cognitive and language outcomes in later childhood. Developmental Science, 11, 339-432. 
Moffitt, T. E., Arseneault, L., Belsky, D., Dickson, N., Hancox, R. J., Harrington, H., ... \& Sears, M. R. (2011). A gradient of childhood self-control predicts health, wealth, and public safety. Proceedings of the National Academy of Sciences, 108(7), 2693-2698.

Morris, D. (2007). Sevmek dokunmaktır (5. Bask1). İstanbul: İnkilap Kitabevi

Müller, U., Liebermann-Finestone, D. P., Carpendale, J. I. M., Hammond, S. I., \& Bibok, M. B. (2012). Knowing minds, controlling actions: The developmental relations between theory of mind and executive function from 2 to 4 years of age. Journal of Experimental Child Psychology, 111, 331-348.

Oberlander, T., Weinberg, J., Papsdorf, M., Grunau, R., Misri, S., \& Devlin, A. (2008). Prenatal exposure to maternal depression, neonatal methylation of human glucocorticoid receptor gene $(\mathrm{NR} 3 \mathrm{C} 1)$ and infant cortisol stress responses. Epigenetics, 3, 97-106.

Orta, I. M., Corapci, F., Yagmurlu, B., \& Aksan, N. (2013). The mediational role of effortful control and emotional dysregulation in the link between maternal responsiveness and Turkish preschoolers' social competency and externalizing symptoms. Infant and Child Development, 22(5), 459-479.

Paulussen-Hoogeboom, M. C., Stams, G. J. J., Hermanns, J. M. A., Peetsma, T. T. D. \& Van den Wittenboer, G. L. H. (2008). Parenting style as a mediator between children's negative emotionality and problematic behavior in early childhood. The Journal of Genetic Psychology, 169, 209-226.

Perner, J., \& Lang, B. (2000). Theory of mind and executive function: Is there a developmental relationship? In S. Baron-Cohen, H. Tager-Flusberg, \& D. J. Cohen (Eds.), Understanding other minds: Perspectives from developmental cognitive neuroscience (2nd ed., pp. 150-181). New York: Oxford University Press.

Peterson, C., Slaughter, V. and Paynter, J. (2007). Social maturity and theory of mind in typically developing children and those on the autism spectrum. Journal of Child Psychology and Psychiatry, 48, 1243-1250.

Pungello, E. P., Iruka, I. U., Dotterer, A. M., Mills-Koonce, R., \& Reznick, J. S. (2009). The effects of socio economic status, race, and parenting on language development in early childhood. Developmental Psychology, 45, 544-557. 
Razza, R. A., \& Blair, C. (2009). Associations among false-belief understanding, executive function, and social competence: A longitudinal analysis. Journal of Applied Developmental Psychology, 30, 332-343.

Rowe, M. L. (2008). Child-directed speech: relation to socioeconomic status, knowledge of child development and child vocabulary skill. Journal of Child Language, 35(1), $185-$ 205 .

Rubin K. H., \& Cheah C. S. L. (2000). The Parental Warmth and Control Scale - Revised, (Yayımlanmamış kodlama klavuzu), University of Maryland, College Park.

Rubin K. H., Cheah C. S. L., \& Fox N. A. (2001). Emotion Regulation, Parenting and Display of Social Reticence in Preschoolers, Early Education and Development: Special Issue on Emotion Regulation, 12, 97-115.

Séguin, J. R., \& Zelazo, P. D. (2005). Executive Function in Early Physical Aggression. In R. E. Tremblay, W. W. Hartup, \& J. Archer (Eds.), Developmental origins of aggression (pp. 307-329). New York: Guilford Press.

Selçuk, B., Yavuz, M., Harma, M., Etel, E., \& Ruffman, T. (2017). Executive function and theory of mind as predictors of socially withdrawn behavior in institutionalized children. Social Development. Online yayım: 30 Haziran 2017. doi: 10.1111/sode. 12252

Selçuk, B., \& Yücel, M. (2017). The role of institutionalization in theory of mind. In V. Slaughter \& M. de Rosnay (Eds.), Theory of mind development in context (pp. 89-105). London: Routledge.

Sibley, B. A., \& Etnier, J. L. (2003). The relationship between physical activity and cognition in children: a meta-analysis. Pediatric Exercise Science, 15 (3), 243-256.

Şen, H., Yavuz, H. M., \& Yağmurlu*, B. (2014). Parenting: The Turkish context. In. H. Selin (Ed.), Parenting across cultures: Childrearing, motherhood and fatherhood in nonwestern cultures. Science across Cultures: The History of Non-Western Science. vol 7. (pp. 175-192). Netherlands: Springer.

Storch, S. A., \& Whitehurst, G. J. (2001). The role of family and home in the literacy development of children from low-income backgrounds. New Directions for Child and Adolescent Development, 2001, 53-72. 
Tamis-LeMonda, C. S., Kuchirko, Y., \& Song, L. (2014). Why is infant language learning facilitated by parental responsiveness? Current Directions in Psychological Science, 23, $121-126$.

Tottenham, N., Hare, T. A., Quinn, B.T., McCarry, T.W., Nurse, M., Gilhooly, T., ...\& Thomas, K.M. (2010). Prolonged institutional rearing is associated with atypically large amygdala volume and difficulties in emotion regulation. Developmental Science, 13, 46-61.

Tyrka, A. R., Price, L. H., Marsit, C., Walters, O. C., \& Carpenter, L. L. (2012). Childhood adversity and epigenetic modulation of the leukocyte glucocorticoid receptor: preliminary findings in healthy adults. PloS one, 7(1), e30148.

Weisleder, A., \& Fernald, A. (2013). Talking to children matters: Early language experience strengthens processing and builds vocabulary. Psychological Science, 24(11), 21432152.

Wellman, H. M., \& Liu, D. (2004). Scaling of theory-of-mind tasks. Child Development, 75, $523-541$.

Woolfe, T., Want, S. C., \& Siegal, M. (2002). Signposts to development: Theory of mind in deaf children. Child Development, 73, 768-778.

Wolters, N., Knoors, E.T.H., Cillessen, H.N.A., \& Verhoeven, L. (2011). Predicting acceptance and popularity in early adolescence as a function of hearing status, gender, and educational setting. Research in Developmental Disabilities, 32, 2553-2565.

Yağmurlu*, B. (2015). Çocuğun sosyal uyum ve sosyal bilgi işleme süreçlerine ebeveyn ve mizacın etkileri: Kültürler arası bir çalışma. Yayınlanmamış TÜBİTAK proje raporu, Proje No: 112K038.

Yağmurlu*, B., \& Sanson, A. (2009). Parenting and temperament as predictors of prosocial behavior in Australian and Turkish-Australian children. Australian Journal of Psychology, 61, 77-88.

Yağmurlu*, B., \& Yavuz, M. (2012). Ana babalığın görünmeyen yönü: Bilişler. In M. Sayil \& B. Yagmurlu (Eds.), Ana-babalık: Kuram ve araştırma (pp. 149-168). Istanbul: Koc Üniversitesi Yayınları. 
Yağmurlu*, B., \& Yavuz, M. (2015). Social competence and temperament in children with chronic orthopedic disability. International Journal of Disability, Development and Education, 62(1), 83-98.

Yavuz, M., Selçuk, B., \& Korkmaz, B. (2017a). Social competence in children with autism. International Journal of Developmental Disabilities. Online basım: 4 Temmuz 2017. doi: 10.1080/20473869.2017.1346224

Yavuz, M, Selçuk, B., Çorapçı, F., \& Aksan, N. (2017b). Role of temperament, parenting behaviors, and stress on Turkish preschoolers' internalizing symptoms. Social Development, 26, 109-128.

Zelazo, P. D., Craik, F. I. M. \& Booth, L. (2004). Executive function across the life span. Acta Psychologica, 115, 167-183

* B. Yağmurlu ve B. Selçuk referansları aynı yazara (Bilge Selçuk’a) aittir. 